\title{
Algılanan Örgütsel Desteğin Duygusal Emek Davranışları Üzerine Etkisi: Afyonkarahisar'daki Beş Yıldızlı Otel İşletmeleri Örneği (The Effect of Perceived Organizational Support on Emotional Labor Behaviors: The Case of Five Star Hotels in Afyonkarahisar)
}

\author{
Mustafa GÜLAYDIN iD a Gonca AYTAŞ iD b \\ a Afyon Kocatepe Üniversitesi, Sosyal Bilimler Enstitüsü, Turizm İşletmeciliği Anabilim Dalı, Afyonkarahisar, Türkiye. \\ mustafagulaydin@gmail.com \\ b Afyon Kocatepe Üniversitesi, Turizm Fakültesi, Turizm İşletmeciliği Bölümü, Afyonkarahisar, Türkiye. kilicgonca@aku.edu.tr
}

\begin{tabular}{|c|c|}
\hline MAKALE BİLGİSİ & '̇ET \\
\hline $\begin{array}{l}\text { Anahtar Kelimeler: } \\
\text { Algılanan Örgütsel Destek } \\
\text { Duygusal Emek } \\
\text { Otel İşletmeleri } \\
\text { Çalışanlar }\end{array}$ & $\begin{array}{l}\text { Amaç - Örgütlerde başarıyı ve verimliliği etkileyen en önemli faktörün insan kaynağı olduğu } \\
\text { gerçeği çalışanların örgütsel destek algısı ve sergiledikleri duygusal emek davranışları gibi } \\
\text { kavramların önemi örgütler açısından giderek artmaktadır. Araştırmada beş yıldızlı otel işlemeleri } \\
\text { çalışanları üzerinde yapılan bir uygulamayla, algılanan örgütsel desteğin duygusal emek } \\
\text { davranışları (yüzeysel davranış, samimi davranış ve derin davranış) üzerindeki etkisinin } \\
\text { araştırılması amaçlanmıştır. }\end{array}$ \\
\hline Gönderilme Tarihi 26 & $\begin{array}{l}\text { Yöntem - Araştırmanının evrenini, Afyonkarahisar'da faaliyet gösteren beş yıldızlı otel } \\
\text { işletmelerinde görev yapan } 544 \text { çalışan oluşturmaktadır. Araştırmada kullanılan veriler } \\
\text { çalışanlardan anket tekniği ile toplanmış ve sosyal bilimlerde kullanılan istatistik paket programı ile } \\
\text { çözümlenmiştir. }\end{array}$ \\
\hline $\begin{array}{l}2020 \\
\text { Revizyon Tarihi } 21 \text { Ekim } 2020 \\
\text { Kabul Tarihi } 28 \text { Ekim } 2020\end{array}$ & $\begin{array}{l}\text { Bulgular - Algılanan örgütsel destek ile samimi davranış ve derin davranış arasında pozitif yönlü } \\
\text { ve anlamı bir ilişkinin olduğu, yüzeysel davranış ile negatif yönlü ve anlamlı bir ilişkinin olduğu } \\
\text { yapılan korelasyon analizi sonucu belirlenmiştir. Bununla birlikte, algılanan örgütsel desteğin } \\
\text { samimi davranış ve derin davranışı pozitif yönlü anlamlı bir şekilde etkilediği, yüzeysel davranş̧ } \\
\text { üzerinde ise negatif yönlü anlamı bir etkisinin olduğu tespit edilmiştir. }\end{array}$ \\
\hline & $\begin{array}{l}\text { Tartışma - Çalışmada elde edilen bulgular konu üzerinde yapılan araştırmaların bulgularını } \\
\text { destekler niteliktedir. Örgütlerin destekleyici olması çalışan davranışlarının ve duygularının } \\
\text { şekillenmesinde önemli bir unsur olduğu görülmüştür. }\end{array}$ \\
\hline
\end{tabular}

Araştırma Makalesi

ARTICLE INFO ABSTRACT

Keywords:

Perceived Organizational Support

Emotional Labor

Hotels

Employees

Afyonkarahisar

Received 26 August 2020

Revised 21 October 2020

Accepted 28 October 2020

Article Classification:

Research Article
Purpose - The fact that the most important factor affecting success and efficiency in organizations is the human resource, and the importance of concepts such as employees' perception of organizational support and the emotional labor behaviors they exhibit are increasing. In the study, it was aimed to investigate the effect of perceived organizational support on emotional labor behaviors (surface acting, genuine acting and deep acting) with an application made on five-star hotel processing employees.

Design/methodology/approach - The universe of his research consists of 544 employees working in five-star hotel businesses operating in Afyonkarahisar. The data used in this study were collected by questionnaires from employees and were analyzed by statistical software package used in the social sciences.

Findings - It was determined as a result of the correlation analysis between perceived organizational support and positive behavior and meaningful relationship between genuine acting and deep acting, and that there was a negative and meaningful relationship with surface acting. However, it was determined that perceived organizational support had a positive and meaningful effect on genuine acting and deep acting, and had a negative effect on surface acting.

Discussion - Findings obtained in the study support the findings of the research on the subject. It is seen that being supportive of organizations is an important factor in shaping employee behavior and emotions.

\section{Önerilen Atıf/ Suggested Citation}

Gülaydın, M., Aytaş, G. (2020). Algılanan Örgütsel Desteğin Duygusal Emek Davranışları Üzerine Etkisi: Afyonkarahisar'daki Beş Yıldızlı Otel İşletmeleri Örneği, İşletme Araştırmaları Dergisi, 12 (4), 3433-3450. 


\section{GİRISS}

Turizm sektöründe turistlerin, konaklama, yeme-içme, eğlenme ve dinlenme gibi ihtiyaçlarının karşılandığ1 konaklama işletmeleri turizmin emek-yoğun özelliği göz önüne alındığında en fazla insan unsurundan yararlanılan hizmet işletmeleridir. Konaklama işletmelerinde üretilen turistik ürünün soyut bir özellik taşıması ve üretildiği yerde tüketilmesinden dolayı kuşkusuz en önemli üretim faktörü ve farklılık yaratmadaki anahtar unsuru insandır (Kaplan, 2010: 1). Küresel rekabet ortamında işletmelerin varlıklarını sürdürebilmeleri için, verimlilik artışı sağlanması ve bu artışın izlenmesi gerekmektedir. Verimliliğin en önemli bileşenleri bireysel ve örgütsel performans değişkenleri olup, bu değişkenlerin temel aktörü ise insan unsurudur (Turunç ve Çelik, 2010: 210).

Turizm sektöründe faaliyet gösteren beş yıldızlı otel işletmeleri şüphesiz konaklama işletmeleri arasında birden fazla çalışanın bir araya gelerek oluşturdukları büyük örgütsel yapıya sahip işletmelerdir. Örgütlerin artan rekabet ortamında devamlılı̆ı̆ın sağlanabilmesi için en önemli kaynaklardan biri olan insan faktörünün etkili bir biçimde yönetilmesi gereklidir (Kılıç, 2008). Bu açından çalışanların yönetilmesi beş yıldızlı otel işletmeleri gibi büyük örgütsel yapılar düşünüldügünde örgütsel başarı, rekabetçi avantaj üstünlüğü yaratma, verimlilik, sunulan hizmet kalitesinin artması gibi durumlar için önem taşımaktadır. Turizm sektörünün özelliklerinden birisi olan üretim ve tüketimin eş zamanlı olması, hizmet sunumu sırasında çalışan ve müşteri etkileşiminin maksimum düzeye çıkması ve çalışanların sergileyeceği davranışlarda yönetim kontrolünün minimum düzeye inmesi durumunu ortaya çıkarmaktadır. Bu durum otel işletmelerindeki örgüt yönetiminin önemini bir kat daha arttırmaktadır. Örgütlerin destekleyici bir yönetim anlayışına sahip olması çalışanların davranışlarını etkileyerek çalışanlardan maksimum verim almada, örgütsel başarının sağlanmasında ve rakiplerine karşı rekabet üstünlüğü sağlamada işletmeye katkı sağlayabilir.

Otel işletmelerinde örgütün bir bireyi olarak görev yapan çalışanlara, örgütleri tarafından sağlanan desteğin çalışanların görevleri sırasında sergileyecekleri davranışları şekillendirmede etkili olacağı söylenebilir. Çalıştıkları otel işletmelerinde çalışanların kendilerine değer verildiğini hissetmeleri ve her durumda bireyi oldukları örgütün kendilerine destek verdiklerine inanmaları, çalışan ile örgüt arasında gönül bağı kurulmasında etkili olmaktadır. Çalışanların algıladıkları bu örgütsel desteğin karşılığını gönüllü ve istekli bir şekilde örgütün amaç ve hedefleri doğrultusunda daha fazla çaba sarf ederek ve çalışarak vermeleri beklenmektedir (Turunç ve Çelik, 2010: 184). Otel işletmelerindeki ürünün hizmet olup bunun da soyut özellik taşıması, üretim ve tüketimin eş zamanlı gerçekleşmesi ve yönetimin çalışan davranışları üzerindeki etkisinin kısıtlı olmasından dolayı ortaya çıkacak duygusal emek davranışının ve örgütün bireye olan desteğinin önemi giderek artmaktadır. Bu nedenle çalışanın örgüte karşı aitlik hissetmesi ve destek görmesi bununla birlikte sergileyeceği duygusal emek davranışını şekillendirmesi, örgütün çalışana karşı destekleyici olmasının önemini bir kat daha arttırmaktadır. Buradan hareketle çalışanların örgütsel destek algısının yüksek olması, sergileyecekleri duygusal emek davranışlarının pozitif eğilimli olmasına ve bunun sonucunda da verimlilik, müşteri memnuniyeti, hizmet kalitesi, örgütsel başarı, rekabet üstünlüğü gibi işletmeye fayda sağlayacak durumların ortaya çıkmasına katkı sağlayacağı söylenebilir. Eisenberger ve diğerleri (1986) çalışanların örgütsel destek algılarının arttıkça örgütün amaç ve hedeflerine ulaşması için örgütün yararına gösterdikleri çabanın da arttığını ortaya koymuşlardır. Gosserand ve Dienfendorrf (2005) yaptıkları çalışmada, çalışanların örgüte karşı olumlu duygulanım içerisinde bulunmalarının, sergileme eğiliminde oldukları duygusal emek davranışlarını olumlu yönde etkilediğini ifade etmişlerdir. Diğer bir çalışmada da benzer şekilde, Rousseau (1995) Çalışanların örgütün için gösterdikleri çabanın karşlığında örgütten yarar elde ettikleri ve bu durumun bir tür karşılıklı değişim ilişkisi olduğunu belirtmektedir. Bu bağlamda çalışanların örgütsel destek algılarının duygusal emek davranışlarıyla ilişkili olduğu düşünülmektedir.

Bu çalışmanın amacı, beş yıldızlı otel işletmeleri çalışanlarının algıladıkları örgütsel desteğin duygusal emek davranışları üzerindeki etkisini tespit etmektir. Dolayısı ile bu çalışma beş yıldızlı otel işletmeleri çalışanlarının algılanan örgütsel destek düzeylerini tespit etmek ve örgütsel destek algıları sonucunda duygusal emek davranışlarına ilişkin görüşlerini belirlemek, ilişkilendirmek ve algılanan örgütsel desteğin duygusal emek davranışları üzerindeki etkisini tespit etmek açısından önem taşımaktadır. Bu çalışma hem daha etkili örgüt ve insan kaynağı yönetimi hem de daha etkili bir işletme yönetimi bakımından yöneticiler için de önem arz etmektedir. 


\section{KAVRAMSAL ÇERÇEVE}

\subsection{Algılanan Örgütsel Destek}

Algılanan örgütsel destek kavramı 1980'li yıllara kadar ortaya konulmamasına karşın örgütsel destek fikri neredeyse yetmiş yıldır yönetim literatüründe yer almaktadır (Zagenczyk, 2006: 8). Algılanan örgütsel destek kavramını ilk kez kullanan Eisenberger ve diğerleri (1986) örgütün çalışanlarını desteklemesinin çalışanların tutum ve davranışları üzerinde etkili olmasından dolayı algılanan örgütsel destek kavramının yönetim ve örgüt alanında önemli bir kavram haline geldiğini vurgulamışlar ve konu ile ilgili yaptıkları birden fazla çalışma ile yönetim literatürünün gelişimine önemli katkılar sağlamışlardır. Örgüt ve çalışan ilişkileri üzerine yapılan çalışmaların önem kazanması örgütün devamlılığının sağlanması, amaç ve hedeflere ulaşmada örgütler için insan faktörünün yanında insanların duygularının da önemli olduğu sonucunu ortaya koymuştur. Bu açından bakıldığında örgütler, insanların maddi ihtiyaçlarını karşılamasının yanı sıra manevi ihtiyaçlarını da karşılamasının zorunluluğunu ortaya koymaktadır. Örgüt tarafından duygusal ihtiyaçları karşılanan çalışanların örgütün büyümesi, gelişmesi, devamlılı̆̆ının sağlanması ve örgütsel başarının artmasında önemli rol oynayacağı söylenebilir.

Algı, bireylerin çevrelerini anlamlı hale getirmek için duyusal izlenimlerini düzenleyip yorumladıkları bir süreçtir (Robbins ve Judge, 2013: 166). Örgütsel boyutta algı ise, çalışanların örgüte karşı bakış açıları ve örgütte oluşan yönetim, adalet ve tarafsızlık gibi algı türlerini nasıl algıladığıdır (Özdevecioğlu, 2003: 116). Dolayısı ile, örgüt ya da yönetim algısı çalışanların örgüt ile ilgili bakış açısını yansıtır (Akbaba, 2011: 69-70). Eisenberger ve diğerleri (1986: 500) tarafından algılanan örgütsel destek, "Örgüt tarafından çalışanların katkılarına değer verildiğine ve mutluluğunun önemsendiğine dair çalışanların duyduğu inanç" şeklinde tanımlanmaktadır. Özdevecioğlu (2003: 113) tarafından ise algılanan örgütsel destek, "örgüt çalışanlarının kendilerini güvende hissetmeleri ve arkalarında örgütün var olduğunu bilmeleri" şeklinde tanımlanmıştır.

Çalışanlar örgüt içerisinde destek alma ve desteklendiklerini hissetme ihtiyacı duyarlar. Örgütsel destek çalışanların saygı duyulma, kabul görme, onay görme ve değer verilme gibi duygusal ihtiyaçlarının karşılanması bakımından son derece önemli bir kaynaktır. Örgüt, çalışanlarına destek vererek çalışanların örgüte olan katkılarının farkında olduğunu, mutluluklarına önem verdiğini ve birlikte örgütün amaç ve hedefleri için çalışmaktan memnuniyet duyduklarını belirterek, çalışanlarının ait olma, saygı ve onay görme ihtiyaçlarını karşılar (Armeli vd., 1998: 296; Özdemir, 2010: 241).

Örgütsel destek algısı, örgütsel değerlerde çalışanların refahının göz önünde tutulması ve bu değerlerin çalışanların mutluluklarını arttırıcı nitelik taşıması durumudur. Buna göre destekleyici bir örgütte veya yönetimde yer alması gereken önemli özellikler çalışanlarının yaratıcı fikirlerini, önerilerini ve eleştirilerini dikkate almak, iş güvenliklerini sağlamak, örgüt içinde insan ilişkilerinin pozitif olmasını sağlamak, herkese adaletli davranmak, hak yememek, çalışanları önemsemek ve onlara rağmen bazı kararları almamak şeklinde sıralanabilir (Eisenberger vd., 1986: 501; Özdevecioğlu, 2003: 116-118; İplik vd., 2014: 111).

Algılanan örgütsel destek ise, örgüt çalışanlarına iş ve iş güvenliği ile ilgili eğitimin verilmesi, yönetimin desteğinin hissettirilmesi, iyi bir örgüt ikliminin oluşturulması, ödüllendirme, kariyer fırsatları ve örgütün işleyişi için teknolojik desteğin sağlanması ile mümkündür (Durmuş ve Şahin, 2015: 439). Çalışanlarda örgütsel destek algısı ihtiyaç duydukları desteğin örgüt tarafından sağlanması ile çalışanların örgütün amaçları için daha fazla çalışması sonucu görülür.

Çalışanların örgütleri tarafından desteklendiklerini hissetmesi örgüte karşı olan davranış ve tutumlarını olumlu yönde etkileyerek örgütün amaçlarına ulaşmasında önemli katkılar sağlayabilir. Zira Eisenberger ve diğerleri (1990) çalışmalarında örgütün, çalışanlarına ihtiyaç duydukları desteği sağlaması, katkılarına değer vermesi ve onları önemsemesi olgularını kapsayan örgütsel destek ile çalışanların örgüte olan duygusal bağlılıkları arasında pozitif yönlü bir ilişkinin olduğunu belirtmiştir. Oktuğ (2013: 374) tarafından yapılan çalışmada çalışanların örgütsel destek algısının olumlu duyguları pozitif olarak etkilediği görülmüştür. Bu yüzden algılanan örgütsel destek, örgütün çalışanlarını fark etmesi, örgütün amaçlarına ulaşması ile çalışanlarının çabalarını görmesi, refahı ve mutluluğu ile gerekli olan bütün imkanları sunması ile ilgilidir. Çalışanların görev yaptıkları örgüt tarafından desteklendiklerini hissetmesi çalışma ortamında görevlerini yerine getirirken hissettikleri duyguları göstermelerinde ve sergilemelerinde çalışanlara katkı sağlayacaktır. 
İş ortamında çalışanların sergiledikleri ve benimsedikleri duygular ve davranışlar duygusal emek olarak adlandırılmaktadır (Hochschild, 1983).

\subsection{Duygusal Emek}

Duygusal emek kavramı ile ilgili ilk çalışmalar Goffman (1959) tarafından yapılmıştır. Goffman çalışanlarda bulunması istenen davranışları ve örgütlerin bununla ilgili denetimlerini gözlemlemiştir (Oğuz ve Özkul, 2016: 132). Goffman'dan etkilenen Amerikalı Sosyolog Arlie Russel Hochschild'da duygusal emek kavramını ilk olarak 1983 yılında “The Managed Heart- Yönetilen Kalp" adlı kitabında ele almıştır (Köse vd., 2011: 168). Delta Havayolları'nda görev yapan kabin memurları üzerine Hochschild (1983: 6)'in yapmış olduğu araştırmada kabin memurlarının ağır servis arabalarını uçağın koridorundan iterken fiziksel, uçak içerisinde acil durumları organize ederken ise zihinsel bir emek sarf ettiğini belirtmiştir. Fiziksel ve zihinsel emek sarf etmenin yanında kabin memurlarının duygusal emek sarf ettiğini de eklemiş ve duygusal emek kavramını literatüre kazandırmıştır.

Hochschild (1983: 6) duygusal emek kavramını “herkes tarafından açıkça gözlenebilen yüz mimikleri ve beden hareketlerinin sergilenmesi amacıyla duyguların yönetilmesi" olarak tanımlamasının yanında, belli bir ücret karşılı̆̆ında yapıldığından dolayı değişebilen bir değer olduğunu da belirtmiştir. Topateş ve Kalfa (2009: 425) tarafından ise duygusal emek "çalışanların müşterilerle yakın ilişkiler kurulmasını gerektiren işlerde işin gereklerini sunabilmek amacıyla sarf edilmek zorunda olunan emek ve duyguların dönüştürülmesi" olarak tanımlamıştır.

Hizmet satılan mesleklerde sunulan hizmetin kalitesini, hizmet sunumu yapan çalışan ile hizmeti satın alan müşteri arasındaki karşılıklı ilişkiler belirlemektedir. Bu doğrultuda hizmet sunumu esnasında örgütler sunulan hizmet ile birlikte, müşterilerine güler yüz ve saygının da çalışanlar tarafından gösterileceğini taahhüt etmektedirler. Bu bağlamda örgütler, hizmet kalitesini garanti altına almak amaciyla hizmet sunumu esnasında çalışanların uyması gereken kuralları belirlemekte ve uygulanması için denetlemektedir. Örgütlerin çalışanlardan uygulamasını istediği ve beklediği bu kuralların gereğini yerine getirmek amacıyla çalışanların duygusal ifadelerini ya da içsel hislerini değiştirmek suretiyle harcadıkları çaba duygusal emek olarak ifade edilmektedir (Eroğlu, 2014: 147-148).

Örgütler insanlardan, insanlar ise duygulardan ayrı düşünülemeyeceğinden dolayı insanların bulunduğu her ortamda ve tabii ki örgütlerde de duygular sürekli olarak varlıklarını korumaktadırlar (Özkan, 2013: 65-66). Örgütler, çalışanlardan kendilerini müşterilerin yerine koymalarını, örgüt tarafından belirlenen ve istenen rolleri sergilemelerini, hissetmelerini ya da çok farklı duygular içerisinde bulunsalar bile örgüt tarafından istenen davranışları göstermelerini beklemektedirler (Eroğlu, 2010: 19; Keleş, 2014: 50). Genel olarak, iş ortamında çalışanların hissettikleri duygular çok çeşitlilik gösterebilir, ancak örgütler tarafından çalışanlarından sergilemelerini istedikleri duygular, yapılan işin niteliğine göre değişmekle beraber, oldukça biçimsellik arz etmektedir (Beğenirbaş ve Meydan, 2012: 164). Örneğin, otel işletmesinde önbüro bölümünde çalışan bir resepsiyon elemanının güler yüzlü olması beklenirken, bir polisin sert ve soğuk kanlı davranışlar sergileyen bir kişi olması beklenir. Bunun sebebi ise çalışılan ortam ve hizmet verilen kişilerin niteliğidir. Duyguların işlevsel hale getirilmesi ve örgütsel hedeflerle bütünleşmesi örgütlerde başarının sağlanmasında etkili rol oynamaktadır. Duygunun, örgütlerin hedefleriyle uyumlu hale getirilmesi aynı zamanda çalışma hayatı içerisinde duyguların önemli bir unsur olmasına ve ticari bir boyut kazanmasına da katkı sağlar (Kart, 2011: 224).

Duygusal emeğin, örgütsel ve yönetsel davranışların sergilenmesinde önemli rolü bulunmaktadır. Özellikle hizmet üretimi yapan işletmelerde çalışanların iletişim becerileri, bireylerarası ilişkileri ve gösterdikleri duygusal çabalar işletme ve örgütlerin hayatta kalması açısından önemli bir kavramdır. Bu yüzden, birçok örgüt çalışanlarından bekledikleri ve istedikleri davranışlarla ilgili kuralları en başta belirleyerek, örgütsel amaçlara ulaşmayı hedeflemektedir (Steinberg ve Figart, 1999; Diefendorf ve Richard, 2008 Akt. Basım ve Beğenirbaş, 2012: 80). Bu sürecin örgüt yönetiminin isteği ve kontrolü altında gerçekleşmesi duygusal emeğin önemli bir unsurudur (Karaman, 2017: 54). Çalışanların duygularını doğru bir biçimde kontrol edip yönetebilen işletmeler, amaç ve hedeflerine ulaşmada başarılı olmakta ve bu durumda duygusal emek ile sağlanmaktadır. Bu bağlamda, duygusal emek işletmeler özellikle de turizm işletmeleri için önemlidir. 
Duygusal emek ile ilgili birçok farklı boyut bulunmaktadır. Bu araştırmada Hochschild (1983) tarafından ortaya konulan yüzeysel davranış ve derin davranış boyutları ile Ashforth ve Humphrey (1993) tarafından ortaya konulan samimi davranış boyutu da eklenerek üç boyutta ele alınmıştır. Gerekli literatür incelendiğinde (Oktuğ, 2013; Yılmaz,2014; Kızanlıklı, 2014; Keleş, 2014; Ayana, 2016) bu üç boyutun duygusal emek davranışını daha iyi açıkladığından ve turizm işletmelerinde bu boyutlar ile daha çok çalışmaya rastlandığından dolayı bu çalışma içinde duygusal emek davranışı bu üç boyutta ele alınmıştır.

Yüzeysel Davranış: “Çalışanın hissettiği duygular ile örgüt tarafından sergilenmesi istenen duygular arasında uyumsuzluk olduğu durumda sergilenen davranış" olarak tanımlanmaktadır (Ashfoth ve Humphrey, 1993: 92-93; Hochschild, 1983: 37). Diğer bir deyişle yüzeysel davranış, çalışanların kendi gerçek duygularından farklı olan, örgüt tarafından istenen duyguları dışsal görünüşlerini değiştirerek (mimik, ses tonu, beden dili) göstermesidir (Onay, 2011: 592). Yüzeysel davranış, çalışanın duyguları hissetmediği halde "maske takarak" davranışta bulunmasını, gerçekten hissettiği duygulardan ziyade işinin gerektirdiği duyguları ifade etmesini, adeta aktör gibi rol oynamasını ifade etmektedir (Çoruk, 2014: 81). Örneğin, otel işletmesinde misafir ilişkileri bölümünde görev yapan çalışanın moralinin bozuk olmasına rağmen, müşterilere mutluymuş gibi görünerek onları güler yüzle selamlaması örgüt tarafından istenen duyguları hissediyormuş gibi sergilemesidir.

Derin Davranış: "Çalışandan sergilemesini istenen duyguları gerçekten hissetmek amacıyla çalışanın gösterdiği çaba" olarak tanımlanmaktadır (Ashfoth ve Humphrey, 1993: 93). Derin davranış, çalışanın işin gerektirdiği duyguları gerçekten hissetmeye çalışmasıdır. Duygusal emeğin bu boyutunda, çalışan farklı başa çıma stratejileri uygulayarak gerçekte hissettiği duyguyu işin gerektirdiğine uygun olacak şekilde değiştirmek için çaba sarf eder. Örneğin, bir anaokulu öğretmenin yaramaz bir öğrenciye duyduğu kızgınlık duygusunun farkına vararak, işini iyi yapabilmek için bu duyguyu olumlu duygularla değiştirmeye çalışması bir derin davranıştır. Benzer şekilde otel işletmesinde görev yapan bir garsonun müşterinin bitmek bilmeyen isteklerine karşı sinirlenmesi ve duygusunun farkına vararak işini iyi yapabilmek için bu duyguyu olumlu duygularla değiştirmeye çalışması yine bir derin davranıştır. Farklı bir biçimde ifade edilirse derin davranış kişinin kendi içinde hissettiği duyguyu iradi bir müdahale ile işe uygun olan duyguyla değiştirmesi anlamına gelmektedir (Başbuğ vd., 2010: 256).

Yapılan çalışmalarda duygusal emek davranışı genel olarak yüzeysel davranış ve derin davranış olmak üzere iki boyut olarak ele alınmaktadır. Fakat Diefendorff ve diğerleri (2005) yapmış oldukları çalışmada, samimi duyguların işletmelerde yüzeysel davranış ya da derin davranıştan daha fazla sergilendiğini ifade etmektedir. Ashforth ve Humphrey (1993) ile Diefendorff ve Gosserand'ın (2003) da öne sürdükleri gibi samimi duyguların sergilenmesinin duygusal emeğin yüzeysel davranış ve derin davranış ile birlikte üçüncü bir davranış türü olarak kabul edilmesi gerektiğini belirtmişlerdir.

Samimi Davranış: Ashforth ve Humphrey (1993: 94) tarafından "çalışanların işini yaparken davranışlarında rol yapma gereği duymadan ve çaba saf etmeden gerçekten hissettiği duyguları sergileyebileceği ve bununda samimi davranış" olduğu şeklinde tanımlamaktadır. Yazarlara göre samimi davranış, örgütün çalışandan sergilemesini beklediği duyguları ve davranışları bazen herhangi bir zorlamaya gerek kalmadan hissetmesi ve sergilemesi olarak ifade edilmektedir. Çalışanlar bu duyguların sergilenmesi sürecinde herhangi bir role bürünmelerine gerek kalmadan hissettikleri duyguları olduğu gibi sergilemektedirler (Biçkes vd., 2014: 100). Örneğin bir öğretmenin sınıfındaki çok sevdiği ve başarılı olan bir öğrencisinin okuldan ayrılması esnasında yaşamış olduğu üzüntü, otel işletmesinde görev yapan bir barmenin üzüntülü bir müşterisini rahatlatmak için içten bir ilgili göstermesi onun gerçek ve samimi duygularını ifade etmektedir (Chu ve Murrmann, 2006: 1182; Basım ve Beğenirbaş, 2012: 79).

\subsection{Algılanan Örgütsel Destek ile Duygusal Emek İlişkisi}

Çalışanların örgütler tarafından beklenen ve istenen duyguları sergilemeleri çalışma ortamı, adalet, güven, örgütsel ödüller ve çalışma koşulları, yönetici desteği, çalışma arkadaşı desteği ve örgütsel destek gibi kavramlarla ilişkili ve ilgilidir. Algılanan örgütsel destek Eisenberger ve diğerleri (1983: 500) tarafından çalışanların örgütün amaç ve hedeflerine katkıda bulunmasına karşılık, örgütün çalışanlarına değer verdiğine ve çalışanların mutluluğunu önemsediğine dair çalışanların duyduğu inanç olarak tanımlanmaktadır. Örgüt tarafından çalışanlara ihtiyaç duydukları desteğin sağlanması ile çalışanların örgütlerine olan bağlılıklarının arttığı ve çalışanların bu sayede olumlu duygulanım içine girdiği yapılan çalışmalar sonucunda ortaya konulmuştur (Yılmaz, 2014: 2). Örgüt çalışanlarının örgüte olumlu duygulanım içinde bulunmalarının, 


\section{Gülaydın - G. Aytaş 12/4 (2020) 3433-3450}

yüzeysel davranış ile negatif yönlü, derin davranış ve gerçek duyguları ile pozitif yönlü bir ilişkisi olduğu görülmektedir (Grosserand ve Dienfendorff, 2005: 1256). Çalışanların duygusal emek sergileme şekilleri örgütsel hedeflere ulaşılması açısından büyük önem taşımaktadır. Çalışanların duygularını örgüte fayda sağlayacak şekilde sergilemesi, örgütün amaçlarının gerçekleşmesine katkı sağlayacaktır. Bu bakımdan, çalışanların örgütsel destek algılarının duygusal emek davranışları üzerinde etkili olduğu düşünülmektedir (Oktuğ, 2013: 371-372).

Literatürde algılanan örgütsel destek ile duygusal emek kavramları arasındaki ilişki ve etkiyi inceleyen çalışma çok fazla bulunmamaktadır. Algılanan örgütsel destek ile duygusal emek kavramları arasındaki ilişki ile ilgili yapılan çalışmalar şu şekilde incelenmiştir.

Anomneze ve diğerleri (2016) yapmış oldukları araştırmada, algılanan örgütsel destek ile yüzeysel davranış ve derin davranış arasında düşük düzeyde pozitif yönlü anlamlı bir ilişkinin olduğunu ifade etmiştir. Kim ve diğerleri (2016) yapmış oldukları çalışmada, algılanan örgütsel desteğin yüzeysel davranış ile negatif yönlü ve anlamlı, derin davranış ile pozitif yönlü ve anlamlı bir ilişkinin olduğunu aktarmıştır. Hur ve diğerleri (2014) tarafından yapılan araştırmada, algılanan örgütsel destek ile yüzeysel davranış arasında bir ilişkiye rastlanmazken, derin davranış ile arasında pozitif yönlü anlamlı bir ilişki olduğu tespit edilmiştir. Yılmaz (2014) yapmış olduğu araştırmada, algılanan örgütsel destek ile yüzeysel davranış, samimi ve derin davranış arasında pozitif yönlü anlamlı bir ilişkinin olduğunu belirtmiştir. Hur ve diğerleri (2012) tarafından yapılan araştırmada, algılanan örgütsel desteğin derin davranış ile pozitif yönlü ve anlamlı bir ilişkiye sahip olduğu, ancak yüzeysel davranış ile arasında bir ilişkiye rastlanmadığı belirlenmiştir. Hur ve Kim (2014) tarafından yapılan çalışmada, tur operatörlerinin örgütsel destek algıları ile derin davranış arasında pozitif yönlü, yüzeysel davranış arasında ise negatif yönlü ve anlamlı bir ilişkinin olduğu sonucuna ulaşılmıştır. Yim (2014) tarafından çalışmasında ise tur rehberlerinin örgütsel destek algıları ile derin davranış arasında pozitif yönlü ve anlamlı bir ilişkinin olduğu, buna karşılık yüzeysel davranış ile arasında bir ilişkiye rastlanmadığını ifade etmiştir.

Lee ve diğerleri (2012) yaptıkları araştırma neticesinde, örgütsel desteğin samimi davranış ve derin davranış üzerinde pozitif yönlü ve anlamlı bir etkisi olduğu, yüzeysel davranış üzerinde ise negatif yönlü anlamlı bir etkinin olduğu sonucuna ulaşıldığını ifade etmişlerdir.

Oktuğ (2013) yapılan araştırmada, algılanan örgütsel destek ile yüzeysel rol yapma davranışı arasında negatif yönlü, derin rol yapma ve samimi duyguları sergileme davranışları arasında ise pozitif yönlü ilişki olduğunu, algılanan örgütsel destek ile duygusal emek davranışları arasındaki en güçlü ilişkinin ise derin rol yapma davranışı olduğunu tespit etmiştir. Bununla birlikte, çalışanların algıladıkları örgütsel desteğin yüzeysel rol yapma ve derin rol yapma davranışları üzerinde negatif yönlü, samimi duygular sergileme davranışı üzerinde iste pozitif yönlü ve anlamlı bir etkisinin olduğu görülmüştür.

Mishra (2013) yapmış olduğu araştırmada, algılanan örgütsel desteğin yüzeysel davranış ile arasında negatif yönlü ve anlamlı, derin davranış ile arasında ise pozitif yönlü ve anlamlı bir ilişki olduğu ve algılanan örgütsel desteğin yüzeysel davranışı negatif yönlü derin davranışı ise pozitif yönlü ve anlamlı bir şekilde etkilediği sonucuna ulaşılmıştır.

Algılanan örgütsel destek ile duygusal emek davranışları arasındaki ilişki genel olarak değerlendirildiğinde, algılanan örgütsel destek ile duygusal emek davranışları arasında anlamlı bir ilişkinin olduğu yapılan çalışmalar neticesinde belirlenmiştir. Konuyla ilgili literatür incelendiğinde, algılanan örgütsel destek ile yüzeysel davranış arasında genel olarak negatif yönlü ve anlamlı bir ilişkinin olduğu tespit edilmiştir (Hur ve Kim, 2014; Kim vd., 2016). Diğer şekilde ifade edilirse, çalışanların üyesi olduğu örgütün desteğine yönelik algılarının yüzeysel davranış sergileme eğilimlerini azalttığı şeklinde ifade edilebilir. Lee ve diğerleri (2012) ve Oktuğ (2013) ve Mishra (2013) tarafından yapılan çalışmalarda ise çalışanların algıladıkları örgütsel desteğin yüzeysel davranış üzerinde pozitif yönlü ve anlamlı bir etkisinin olduğunu tespit edilmiştir. Bu doğrultuda araştırmanın birinci hipotezi şu şekilde oluşturulmuştur.

H1: Otel işletmeleri çalışanlarının örgütsel destek algılarının yüzeysel davranış üzerinde negatif yönlü ve anlamlı bir etkisi vardır.

Yapılan çalışmalarda algılanan örgütsel destek ile samimi davranış arasında pozitif yönlü ve anlamlı bir ilişkinin olduğu belirlenmiştir (Lee vd., 2012; Oktuğ, 2013; Yılmaz, 2014). Farklı bir şekilde ifade edilirse 
çalışanların örgütsel destek algıları çalışanlarda samimi davranışı sergileme eğilimini arttırdığı söylenebilir. Aynı zamanda Lee ve diğerleri (2012) ve Oktuğ (2013) tarafından yapılan çalışmalarda çalışanların örgütsel destek algılarının samimi davranışı pozitif yönlü ve anlamlı bir şekilde etkilediği belirlenmiştir. Bu bilgilerden hareketle araştırmanın ikinci hipotezi şu şekilde oluşturulmuştur.

\section{$\mathbf{H}_{2:}$ Otel işletmeleri çalı̧anlarının örgütsel destek algllarının samimi davranışüzerinde pozitif yönlü ve anlamlı bir etkisi vardir.}

İlgili literatür incelendiğinde, algılanan örgütsel destek ile derin davranış arasında ise genel olarak pozitif yönlü ve anlamlı bir ilişkinin olduğu belirlenmiştir (Hur vd., 2012; Yim, 2014; Hur vd., 2014; Hur ve Kim, 2014; Yılmaz, 2014; Anomneze vd., 2016; Kim vd., 2016). Bu durum örgütün çalışanlarını destekleyici bir şekilde davranması ile çalışanların işlerini daha iyi bir şekilde yapabilmek için örgüt tarafından istenen ve beklenen duyguları hissetmeye çalışması ve bu duyguları hizmet sunumu esnasında müşteriye yansıtması ile ilgilidir. Lee ve diğerleri (2012) ve Mishra (2013) tarafından yapılan çalışmalarda çalışanların algıladıkları örgütsel desteğin sergiledikleri derin davranış üzerinde pozitif yönlü ve anlamlı bir etkisinin olduğu saptanmıştır. Bu doğrultuda araştırmanın üçüncü hipotezi şu şekilde oluşturulmuştur.

$\mathbf{H}_{3}$ : Otel işletmeleri çalışanlarının örgütsel destek algılarının derin davranış üzerinde pozitif yönlü ve anlaml bir etkisi vardir.

\section{YÖNTEM}

\subsection{Verilerin Toplanması}

Uygulamalı bir nitelik taşıyan bu araştırmada; beş yıldızlı otel işletmelerinde çalışanların algıladıkları örgütsel desteğin duygusal emek davranışları üzerindeki etkisinin belirlenmesi amacıyla anket tekniği ile veriler bilimsel araştırma projeleri kapsamında 2018 yılı Haziran ve Ağustos ayları arasında toplanmıştır. Beş yıldızlı otel işletmeleri çalışanlarından veri toplamak amacıyla uygulanan anket formu 3 bölümden oluşmaktadır. Anketin birinci bölümünde; çalışanların bazı bireysel özellikleri ve işletmeye ait özelliklerini belirlemeyi amaçlayan 10 kapalı uçlu soruya yer verilmiştir. Anketin ikinci bölümünde; çalışanların anket uygulaması ile algılanan örgütsel destek düzeylerini belirlemek amacıyla ölçeğin dil geçerliliği için Yılmaz (2016) ve Kaya (2012)'nın çalışmalarında yer alan, Eisenberger ve diğerleri (1986: 502) tarafından geliştirilen 36 ifadeden oluşan örgütsel destek ölçeğinin kısaltılmış versiyonu olan, Rhoades ve Eisenberger (2002: 699) tarafından önerilen 8 ifadelik tek boyuttan oluşan ölçek kullanılmıştır. Anketin üçüncü bölümünde ise; çalışanların duygusal emek davranışlarını belirlemek amacıyla ölçeğin dil geçerliliğ̆i Kızanlıklı (2014)'nın çalışmasında yer alan, Chu ve Murmann (2006)'nn Brotheridge ve Lee (2003), Delay (1999), Grandey (1999), Kruml ve Geddes (2000)'ın çalışmalarından yola çıkarak ağırlama sektörü için iki boyutlu olarak geliştirdiği Konukseverlik Duygusal Emek Ölçeği (Hospitality Emotinal Labour Scale-HELS)'nin araştırmacılara önerdiği 19 ifadelik hali kullanılmıştır (Chu ve Murrmann, 2006: 1188). Duygusal Emek Ölçeği'nin 11 ifadesi "yüzeysel davranış" ve "samimi davranış" türlerini temsil eden duygusal çelişki boyutuna ait ifadelerden oluşmakta iken; 8'i duygusal emeğin "derin davranış" türünü temsil eden duygusal çaba boyutuna ait ifadelerdir. Ölçekte yer alan ifadeler (1) Hiç Katılmıyorum ve (5) Tamamen Katılıyorum şeklinde derecelendirilmiştir.

\subsection{Evren ve Örneklem}

Araştırmanın evreni, Afyonkarahisar'da faaliyet gösteren beş yıldızlı otel işletmelerinin çalışanlarından oluşmaktadır. Araştırmacının bulunduğu yere daha fazla katkı sağlaması ve geliştirme isteği amacıyla bununla birlikte zaman, maliyet ve ulaşılabilirliğinden dolayı Afyonkarahisar ilinin evren olarak seçilmesi uygun görülmüştür. Araştırma kapsamını beş yıldızlı otel işletmelerinin oluşturmasının nedeni, bu tür işletmelerin yönetim yapısının ve örgütlenmelerinin diğer otel işletme türlerine (bir yıldızlı, iki yıldızlı, üç yıldızlı ve dört yıldızlı) göre daha profesyonel olarak faaliyet göstermeleridir (Pelit, 2011: 125).

Afyonkarahisar İl Kültür ve Turizm Müdürlügü (2018) verilerine göre Afyonkarahisar ilinde 2018 yılı itibariyle Merkezde 7 adet, Sandıklı ilçesinde ise 3 adet faaliyet gösteren beş yıldız otel işletmesi bulunduğu ve bu tesislerin toplam oda sayısının 2986 olduğu tespit edilmiştir (www.afyonkulturturizm.gov.tr). Bu işletmelerdeki çalışan sayısı ile ilgili net bir sayıya ulaşılamadığı ancak Kültür ve Turizm Bakanlı̆̆ı'nın Türkiye'deki oda sayısı başına düşen personel sayısının 1,18 olduğu (Ağaoğlu, 1992: 114) dikkate alındığında $2986^{*} 1,18=3523$ personel sayısına ulaşılmış olup, bu sayı evrenin $\mathrm{N}<10.000^{\prime}$ den küçük olduğunu (sınırlı evren) 
ortaya koymaktadır. Karasar (2008: 11); zaman, maliyet, ulaşılabilirlik ve kontrol güçlükleri gibi nedenler göz önüne alındığında, araştırmada evrenin tamamı yerine, bilimsel yöntem kurallarına göre örneklem alma yoluna gidilerek çalışanlara anket uygulaması gerçekleştirilmiştir. Evreni temsil düzeyine sahip örneklemin seçiminde olasılık dışı örnekleme yöntemlerinden kolay örnekleme yöntemi kullanılmıştır. Afyonkarahisar' daki beş yıldızlı otel işletmelerinde çalışanların sayısı on binden küçük olduğundan dolayı, sinırlı evrenler $(\mathrm{N}<10.000)$ ve nicel araştırmalar için önerilen örnekleme hacmi hesaplama formülünden yararlanılarak (Özdamar, 2001: 257; Ural ve K1lıç, 2018: 41-43) minimum örneklem sayıs1 346 olarak hesaplanmıştır.

Araştırmada hedeflenen örneklem sayına ulaşılması amacıyla 2018 yılı Haziran ve Ağustos ayları arasında Afyonkarahisar ilindeki beş yıldızlı otel işletmelerine toplamda 600 adet anket dağıtılmıştır. Sonuç olarak geriye dönen anket sayısı 570 adet olup, eksik ve hatalı doldurulma nedeniyle 26 adet anket değerlendirilmeden çıkartılarak 544 adet anket analiz işlemine dâhil edilmiştir.

\subsection{Verilerin Analizi}

Beş yıldızlı otel işletmeleri çalışanlarının algıladıkları örgütsel desteğin duygusal emek davranışları üzerine etkisini belirlemeye yönelik yapılan bu çalışmada elde edilen veriler sosyal bilimlerde kullanılan istatistik paket programı ile çözümlenmiştir. Afyonkarahisar da faaliyet gösteren beş yıldızlı otel işletmeleri çalışanlarının bireysel ve işletmeye yönelik özelliklerine ilişkin veriler yüzde ve frekans yöntemiyle çözümlenmiştir. Bununla birlikte, çalışanların algılanan örgütsel destek düzeyleri ile sergiledikleri duygusal emek davranışlarını belirleyemeye yönelik aritmetik ortalama ve standart sapma değerleri hesaplanmıştır. Araştırmada kullanılan ölçeklerin güvenirliğini ve geçerliğini belirlemek amacıyla Cronbach's Alpha değerleri hesaplanmış ve yapı geçerliği için ise faktör analizi uygulanmışır.

Beş yıldızlı otel işletmeleri çalışanlarının örgütsel destek algıları ile duygusal emek davranışları arasındaki ilişki Pearson korelasyon katsayısı ile belirlenmiştir. Bununla birlikte, çalışanların algıladıkları örgütsel desteğin duygusal emek davranışları üzerindeki etkisi basit doğrusal regresyon analizi ile tespit edilmiştir.

\section{BULGULAR VE TARTIŞMA}

Araştırmaya katılan beş yıldızlı otel işletmeleri çalışanlarının bireysel ve işletmeye ait özelliklerine yönelik bulgular incelendiğinde, araştırmaya katılan bireylerin çoğunluğunun $(\% 52,8)$ ile erkek ve $23-27$ yaş arası $(\% 34,0)$ ve evli $(\% 59,7)$ çalışanlardan oluştuğu görülmüştür. Katılımcıların çoğunluğunun $(\% 37,3)$ 2-4 yıl arası turizm sektöründe ve şu an görev yaptıkları işletmede $(\% 79,8)$ daimî olarak çalıştığı belirlenmiştir. Bu durum yıl boyu faaliyet gösteren şehir otellerinin turizm sektöründe sayfiye otellerine göre çalışanlara daimî olarak çalışma imkânı sunduğu şeklinde yorumlanabilir. Bireylerin çoğunluğunun ortaöğretim (lise) $(\% 46,3)$ mezunu ve turizm alanında eğitim almamış (\%49,8) kişilerden oluştuğu belirlenmiştir. Bu bağlamda otel işletmelerinde çalışanların yarısına yakınının turizm alanında eğitim almayan kişilerden oluştuğu görülmüştür. Bu durumun sebebi olarak turizm alanında elde edilen gelirin düşük olması, fazla ve düzensiz çalışma saatleri, mesai ödemelerinin yapılmaması vb. gibi sebeplerden dolayı turizm alanında eğitim alan kişilerin farklı sektörlere yöneldiği biçiminde yorumlanabilir. Gelir düzeyleri incelendiğinde ise çalışanların çoğunluğu 1601-2500 TL arası gelire sahip $(\% 52,8)$ bireylerden oluştuğu saptanmıştır. Katılımcıların otel işletmelerinde çalıştıkları departmana ilişkin bilgiler incelendiğinde otel işletmelerindeki departmanların istihdam yoğunluğuna bağlı olarak $(\% 25,9)$ ile yiyecek-içecek departmanında, $(\% 23,2)$ ile kat hizmetleri departmanında, $(\% 13,8)$ ile önbüro departmanında, $(\% 7,7)$ ile fitness\&spa departmanında, $(\% 7,0)$ ile satış-pazarlama departmanında, $(\% 5,7)$ ile misafir ilişkileri departmanında, $(\% 4,8)$ ile insan kaynakları departmanında ve çalışan sayısının fazla olmadığı "diğer" diye adlandırılan (güvenlik, muhasebe, teknik servis vb.) departmanlarda $(\% 11,9)$ görev aldıkları belirlenmiştir.

Beş yıldızlı otel işletmeleri çalışanlarının algıladıkları örgütsel desteğin sergiledikleri duygusal emek davranışları üzerine etkisini belirlemek amacıyla bu araştırmada kullanılan algılanan örgütsel destek ölçeği ile duygusal emek ölçeğine ilişkin yapı geçerliği ve güvenirlik düzeylerini tespit etmeye yönelik açıklayıcı faktör analizi ile Cronbach's Alpha değerleri Tablo 1 ve Tablo 2'de verilmiştir. Araştırma verilerinin normal dağılım gösterip göstermediğine ilişkin yapılan normallik testi sonucunda araştırmada kullanılan ölçeklere ait ifadelere ilişkin çarpıklık (skewness) ve basıklık (kurtosis) değerlerinin $-1,0$ ile $+1,0$ arasında olduğu ve Hair ve diğerlerine (2014: 34) göre verilerin normal dağılım gösterdiği belirlenmiştir. 
Tablo 1'de Alg1lanan Örgütsel Destek Ölçeği'ne yönelik yapılan Bartlett's testi sonucunda $(p=0,000<0,05)$ faktör analizine alınan değişkenler arasında ilişkinin olduğu tespit edilmiş ve yapılan test sonucu $(\mathrm{KMO}=0,817>0,60)$ örneklem büyüklüğünün faktör analizi uygulanması için yeterli olduğu belirlenmiştir. Faktör analizlerinde 100'ün üzerindeki katılımcının olduğu tüm örneklemlerde ve faktör yüklerinin 0,50'in üzerinde olduğu analizlerde sonuçlar istatistiksel olarak anlamlı alınmaktadır (Çoşkun vd., 2017: 277).

Tablo 1. Algılanan Örgütsel Destek Ölçeğinin Açıklayıcı Faktör Analizi ve Güvenirlik Düzeyine Yönelik Bulgular

\begin{tabular}{|c|c|}
\hline İfadeler & $\begin{array}{c}\text { Faktör } \\
\text { 1.(Algılanan Örgütsel Destek) }\end{array}$ \\
\hline Calıștığım otel, otelin iyiliğine yönelik yaptığım katkulara değer verir. & 0,822 \\
\hline Çalıştığım otel, gösterdiğim ekstra çabayı takdir etmez. & 0,898 \\
\hline Çalıștığım otel, şikayetlerimi dikkate almaz. & 0,871 \\
\hline Çalıştı̆̆ım otel, gerçekten iyiliğ̈imi düşünür. & 0,836 \\
\hline Çalıştığım otel, ișimi mümkün olan en iyi șekilde yapsam bile bunu fark etmez. & 0,740 \\
\hline Çalıştığım otel, genel olarak işimle ilgili memnuniyetimi önemser. & 0,795 \\
\hline Çalıştı̆̆ım otel, bana çok az yakınlık gösterir. & 0,832 \\
\hline Çalıștığım otel, işimdeki başarılarımla gurur duyar. & 0,828 \\
\hline Özdeğer & 5,499 \\
\hline Toplam Varyansı Açıklama Oranı (\%) & 70,560 \\
\hline Genel Güvenirlik Düzeyi $(\alpha)$ & 0,833 \\
\hline
\end{tabular}

1.Faktör: Algilanan Örgütsel Destek; $\alpha$ : Cronbach's Alpha Değeri; Kaiser-Meyer-Olkin değeri (KMO)=0,817; Bartlett's Testi: X²=2152,398; $p=0,000$

Bununla birlikte faktör yükleri değerinin 0,45 veya daha yüksek olması, seçim için iyi bir ölçü olurken uygulamada daha az sayıdaki madde için bu sınır değeri 0,30'a kadar düşürülebilmektedir (Büyüköztürk, 2003: 124). Faktör analizi uygulamasında varimax yöntemi seçilerek faktörler arası ilişkinin yapısının aynı kalması sağlanmıştır. Faktör analizi sonucuna göre faktör yüklerinin 0,740 ile 0,898 arasında değişiklik gösterdiği tespit edilmiştir. Bununla birlikte, faktör analizinde ölçeğin öz değerinin 1'den büyük ve toplam açıklanan varyansın \%70,560 olan tek faktör altında toplandığı belirlenmiştir. Açıklanan varyans değerine göre Algılanan Örgütsel Destek Ölçeği'nin geçerli bir ölçme aracı olduğu anlaşılmıştır. Bununla birlikte, Algılanan Örgütsel Destek Ölçeği'ne ilişkin Cronbach's Alpha değeri incelendiğinde $(\alpha=0,833)$ olarak hesaplandığı 1 ve ölçeğin güvenilir olduğu belirlenmiştir. Ural ve Kılıç (2018: 268) güvenirlik katsayısı için 0 ile 1 arasında değerler alındığını ve sonuç değerin 1'e yakın olmasının güvenirlik düzeyinin yüksek olduğu anlamına geldiğini belirtmiştir.

Tablo 2. Duygusal Emek Ölçeğinin Açıklayıcı Faktör Analizi ve Güvenirlik Düzeyine Yönelik Bulgular

\begin{tabular}{lccc}
\multicolumn{1}{c}{ İfadeler } & \multicolumn{3}{c}{ Faktörler } \\
\cline { 2 - 4 } & $\mathbf{1 . ( D e r i n )}$ & $\mathbf{2 . ( Y u ̈ z e y s e l )}$ & 3.(Samimi) \\
\hline Müşterilerle etkileşim halindeyken mutluymuşum gibi yaparım. & $-0,154$ & $\mathbf{0 , 5 7 3}$ & 0,271 \\
\hline $\begin{array}{l}\text { Müşterilerle ilgilenirken göstermiş olduğum duygular } \\
\text { hissettiklerimden farklıdır. }\end{array}$ & $-0,088$ & $\mathbf{0 , 8 1 9}$ & 0,056 \\
\hline $\begin{array}{l}\text { İşim ile ilgili gerçek duyguları ifade ederken sahte yüz ifadeleri } \\
\text { takınırım. }\end{array}$ & $-0,040$ & $\mathbf{0 , 7 3 0}$ & 0,023 \\
\hline $\begin{array}{l}\text { Davranışlarımla gerçekte hissettiklerim birbirlerinden farklıdır. } \\
\text { Müşterilerle uygun şekilde ilgilenebilmek için rol yaparım. }\end{array}$ & $-0,017$ & $\mathbf{0 , 8 3 0}$ & 0,015 \\
\hline Müşterilerle oldukça yapay bir etkileşim içerisindeyim. & 0,003 & $\mathbf{0 , 7 3 2}$ & $-0,036$ \\
\hline $\begin{array}{l}\text { Gerçekte hissetmediğim duyguları sergilerim. } \\
\text { Müşerilerle ilgilenirken gerçek duygularımı gizlemek zorunda kalırım. }\end{array}$ & 0,021 & $\mathbf{0 , 7 9 8}$ & $-0,070$ \\
\hline $\begin{array}{l}\text { Müşterilere yansıttığım duygular, gerçekte hissettiklerimle bire bir } \\
\text { uyumludur. }\end{array}$ & 0,317 & $\mathbf{0 , 8 0 3}$ & $-0,155$ \\
\hline $\begin{array}{l}\text { İşimi iyi yapmak için göstermem gereken duyguları gerçekten } \\
\text { hissederim. }\end{array}$ & $0,0,0549$ & $-0,072$ \\
\hline Hissettiğim duyguları müşterilere aynen yansıtırım. & $-0,025$ & $\mathbf{0 , 7 0 9}$ \\
\hline $\begin{array}{l}\text { Duygularımı, müşterilere göstermem gerektiği şekilde değiştirerek } \\
\text { yansıtmaya çalışırım. }\end{array}$ & $\mathbf{0 , 6 9 8}$ & $-0,143$ & 0,106 \\
\hline
\end{tabular}


Müşterilerle etkileşim halindeyken otelin istediği imajı sunmak üzere kendimde bazi duygular yaratmaya gayret ederim.

0,743

0,828

Çalışmaya hazırlanırken iyi şeyler düşünürüm.

Müşterilere yardım ederken hissettiğim şeyleri, gerçekten hissetmekten kurtulmak için, kendimi ikna etmeye çalışırım.

\begin{tabular}{|c|c|c|c|}
\hline İşe hazırlanırken kendime iyi bir gün geçireceğimi söylerim. & 0,825 & 0,034 & 0,106 \\
\hline $\begin{array}{l}\text { Müşterilerle etkileşimde bulunurken göstermek zorunda olduğum } \\
\text { duyguları yaşamaya çalışırım. }\end{array}$ & 0,818 & 0,029 & 0,222 \\
\hline $\begin{array}{l}\text { Müşterilere göstermem gereken duyguları gerçekten hissetmek için } \\
\text { elimden gelen her şeyi yaparım. }\end{array}$ & 0,829 & 0,048 & 0,206 \\
\hline $\begin{array}{l}\text { Gerçekten hissettiğim bir duyguyu göstermek istediŏimde, } \\
\text { davranışlarıma daha fazla konsantre olmak zorunda kalırım. }\end{array}$ & 0,651 & $-0,077$ & 0,247 \\
\hline Özdeğer & 5,190 & 4,698 & 2,204 \\
\hline Varyansı Açıklama Oranı (\%) & 27,317 & 24,728 & 11,600 \\
\hline Toplam Varyansı Açıklama Oranı (\%) & & 63,644 & \\
\hline Faktörlere Yönelik Güvenirlik Düzeyi $(\alpha)$ & 0,910 & 0,894 & 0,857 \\
\hline Genel Güvenirlik Düzeyi $(\alpha)$ & & 0,868 & \\
\hline
\end{tabular}
0,909; Bartlett's Testi: $X^{2}=5993,898 ; p=0,000$

Tablo 2'de Duygusal Emek Ölçeği'ne yönelik yapılan Bartlett testi sonucu $(p=0,000<0,05)$ faktör analizine alınan değişkenler arasında ilişkinin olduğu belirlenmiştir. Yapılan test sonucu $(\mathrm{KMO}=0,909>0,60)$ örneklem büyüklüğünün faktör analizi uygulanması için yeterli olduğu tespit edilmiştir. Faktör analizi sonucuna göre faktör yüklerinin 0,573 ile 0,830 arasında değişiklik gösterdiği görülmektedir. Bununla birlikte, faktör analizinde ölçeğin öz değerinin 1'den büyük ve toplam açıklanan varyansın \%63,644'ünü açıklayan 3 boyutta (faktör) altında toplandığı belirlenmiştir. Boyutlar açısından bakıldığında ise beş yıldızlı otel işletmeleri çalışanlarının sergiledikleri duygusal emek davranışlarını belirlemeye yönelik uygulanan ölçekte "derin davranış" boyutu toplam varyansın \% 27,317 'sini, ikinci faktör "yüzeysel davranış" boyutu toplam varyansın \%24,728'ini, üçüncü faktör ise "samimi davranış" boyutu toplam varyansın \%11,600'ünü açıkladığ1 görülmektedir. Açılanan varyans değerine göre Duygusal Emek Ölçeği'nin geçerli ölçme aracı olduğu anlaşılmıştır. Duygusal Emek Ölçeği ile alt boyutlarına ilişkin Cronbach's Alpha değeri incelendiğinde Duygusal Emek Ölçeği'nin genel güvenirlik düzeyi $(\alpha=0,868)$ olarak hesaplanmıştır. Duygusal emeğin, yüzeysel davranış boyutunun $(\alpha=0,894)$ olarak, samimi davranış boyutunun $(\alpha=0,857)$ olarak, derin davranış boyutunun Cronbach's Alpha katsayısının $(\alpha=0,910)$ olarak hesaplandığı ve oldukça güvenilir oldukları belirlenmiştir.

Algılanan örgütsel destek ile duygusal emek davranışları arasındaki ilişkiye yönelik gerçekleştirilen “Korelasyon Analizi (Pearson Korelasyon Katsayısı) sonuçları Tablo 3'te verilmiştir. Bulgular incelendiğinde, algılanan örgütsel destek ile duygusal emek davranışları (yüzeysel davranış, samimi davranış, derin davranış) arasında 0,001 anlamlılık düzeyinde önemli bir ilişkinin olduğu görülmektedir. Diğer bir şekilde ifade edilecek olursa tüm faktörler arasındaki Pearson Korelasyon Katsayısının ( $\mathrm{r}$ ) istatistiksel olarak anlamlıdır ( $<<0,001)$.

Algılanan örgütsel destek ile duygusal emek davranışları arasındaki ilişkiye ait korelasyon katsayıları incelendiğinde çalışanların örgütsel destek algıları ile duygusal emek davranışları arasında en yüksek ilişki içerisinde olduğu davranışın "samimi davranış" boyutu $(r=0,491)$ olduğu, ilişkinin orta düzeyde anlamlı bir ilişki olduğu tespit edilmiştir. Konuyla ilgili literatür incelendiğinde benzer şekilde algılanan örgütsel destek ile samimi davranış arasında pozitif yönlü ve anlamlı bir ilişkinin olduğu (Lee vd., 2012; Oktuğ, 2013; Yılmaz, 2014) görülmüştür. 
Tablo 3. Algılanan Örgütsel Destek ile Duygusal Emek Davranışları Arasındaki İlişkiye Yönelik Korelasyon Analizi

\begin{tabular}{|c|c|c|c|c|c|}
\hline Değişkenler & & $\begin{array}{c}\text { Algılanan } \\
\text { Örgütsel } \\
\text { Destek }\end{array}$ & $\begin{array}{l}\text { Yüzeysel } \\
\text { Davranış }\end{array}$ & $\begin{array}{c}\text { Samimi } \\
\text { Davranış }\end{array}$ & Derin Davranış \\
\hline \multirow{3}{*}{ Algılanan Örgüitsel Destek } & $r$ & - & & & \\
\hline & $p$ & - & & & \\
\hline & $n$ & - & & & \\
\hline \multirow{3}{*}{ Yüzeysel Davranış } & $r$ & $-0,246^{* *}$ & - & & \\
\hline & $p$ & 0,000 & - & & \\
\hline & $n$ & 544 & - & & \\
\hline \multirow{3}{*}{ Samimi Davranış } & $r$ & $0,491^{* *}$ & $-0,033$ & - & \\
\hline & $p$ & 0,000 & 0,438 & - & \\
\hline & $n$ & 544 & 544 & - & \\
\hline \multirow{3}{*}{ Derin Davranış } & $r$ & $0,456^{* *}$ & $-0,064$ & $0,605^{* *}$ & - \\
\hline & $p$ & 0,000 & 0,134 & 0,000 & - \\
\hline & $n$ & 544 & 544 & 544 & - \\
\hline
\end{tabular}

${ }^{* *} p<0,001 ; r$ : Pearson Korelasyon Katsayısı; $n$ : Birey Sayısı

Algılanan örgütsel destek ile duygusal emeğin diğer bir boyutu olan "derin davranış" boyutu (r=0,456) ile de orta düzeyde anlamlı bir ilişkiye sahip olduğu saptanmıştır. Konuyla ilgili literatürde yapılan çalışmalarda da benzer sonuçlar ortaya konmuş algılanan örgütsel destek ile derin davranış arasında pozitif yönlü ve anlamlı bir ilişkinin olduğu (Lee vd., 2012; Hur vd., 2012; Oktuğ, 2013; Mishra, 2013; Yim, 2014; Hur ve Kim, 2014; Hur vd., 2014; Y1lmaz, 2014; Anomneze vd., 2016; Kim vd., 2016) tespit edilmiştir.

Çalışanların örgütsel destek algıları ile duygusal emeğin "yüzeysel davranış" boyutu $(r=-0,246)$ arasında ise düşük düzeyde anlamlı bir ilişkinin olduğu belirlenmiştir. Konuya ilişkin yapılan çalışmalarda da benzer şekilde algılanan örgütsel destek ile yüzeysel davranış arasında negatif yönlü ve anlamlı bir ilişkinin olduğu (Lee vd., 2012; Oktuğ, 2013; Mishra, 2013; Hur ve Kim, 2014; Kim vd., 2016) belirlenmiştir.

Araştırma bulgularının değerlendirme sürecinde algılanan örgütsel destek ile duygusal emek davranışları arasındaki ilişkinin değerlendirilmesinden sonra araştırma hipotezlerinin test edilmesi amacıyla basit doğrusal regresyon analizi gerçekleştirilmiş ve bulgular Tablo 4, Tablo 5 ve Tablo 6' da sunulmuştur.

Tablo 4. Algılanan Örgütsel Desteğin Yüzeysel Davranış Üzerindeki Etkisine Yönelik Basit Doğrusal Regresyon Analizi

\begin{tabular}{lccccc}
\hline Bağımsız Değişken & $\boldsymbol{\beta j}$ & $\mathbf{S}(\mathbf{b j})$ & $\mathbf{t}$ & $\mathbf{p}$ & Anlamlılık \\
\hline Sabit & 4,256 & 0,162 & 26,316 & 0,000 & $\mathrm{~F}=34,798$ \\
$\mathrm{p}$ Algılanan Örgütsel Destek & $-0,275$ & 0,047 & $-5,899$ & 0,000 & $\mathrm{p}=0,000 * *$ \\
\hline
\end{tabular}

Yüzeysel Davranış $=4,256+(-0,275) *$ Algılanan Örgütsel Destek

**: $p<0,001 ; R^{2}=0,060 ;$ Bă̆ımlı Değ̈işken: Yüzeysel Davranış

Algılanan örgütsel destek ile yüzeysel davranış arasındaki ilişkiyi belirlenmesi amacıyla yapılan regresyon analizi istatistiksel olarak anlamlı bulunmuştur ( $\mathrm{F}=34,798 ; \mathrm{P}=0,000)$. Yüzeysel davranışın belirleyicisi olarak algılanan örgütsel destek değişkeni ile ilişkinin (açıklayıcı gücünün) zayıf olduğu görülmektedir $\left(\mathrm{R}^{2}=0,060\right)$. Çalışanların algıladıkları örgütsel desteğin yüzeysel davranışı negatif ve anlamlı olarak etkilediği tespit edilmiştir $(\beta \mathbf{j}=-0,275)$. Bu doğrultuda, “H1: Otel işletmeleri çalışanlarının örgütsel destek algılarının yüzeysel davranış üzerinde negatif yönlü ve anlamlı bir etkisi vardır" hipotezinin desteklendiği tespit edilmiştir.

İlgili literatür incelendiğinde, Lee ve diğerleri (2012) tarafından yapılan çalışma sonucunda da çalışanların algıladıkları örgütsel desteğin çalışanların sergilediği yüzeysel davranış üzerinde negatif yönlü ve anlamlı bir etkisinin olduğunu belirtmiştir. Konuyla ilgili benzer çalışmalarda da algılanan örgütsel desteğin yüzeysel davranış üzerinde pozitif yönlü ve anlamlı bir etkisinin olduğu görülmüştür (Oktuğ, 2013; Mishra, 2013). Bu sonucun otel işletmelerindeki örgütsel yapının destekleyici olması çalışanların yüzeysel davranışlarını diğer 
bir ifade ile hissetmeden sergilediği duygu ve davranışlarını negatif yönlü etkileyebileceği ve yüzeysel davranış sergileme eğilimlerini düşürebileceği şeklinde yorumlamak mümkündür.

Tablo 5. Algılanan Örgütsel Desteğin Samimi Davranış Üzerindeki Etkisine Yönelik Basit Doğrusal Regresyon Analizi

\begin{tabular}{lccccc}
\hline Bağımsız Değişken & $\boldsymbol{\beta j}$ & $\mathbf{S}(\mathbf{b j})$ & $\mathbf{t}$ & $\mathbf{p}$ & Anlamlılık \\
\hline Sabit & 1,398 & 0,163 & 8,589 & 0,000 & $\mathrm{~F}=172,622$ \\
Algılanan Örgütsel Destek & 0,616 & 0,047 & 13,139 & 0,000 & $\mathrm{p}=0,000 * *$ \\
\hline
\end{tabular}

Samimi Davranıs $=1,398+0,616$ * Algılanan Örgütsel Destek

**: $p<0,001 ; R^{2}=0,242 ;$ Bă̆ımlı Değişken: Samimi Davranıs

Algılanan örgütsel destek ile samimi davranış arasındaki ilişkinin belirlenmesi amacıyla yapılan basit regresyon analizi sonucunda istatistiksel olarak anlamlı olduğu belirlenmiştir ( $F=172,622 ; \mathrm{P}=0,000)$. Samimi davranışın belirleyicisi olarak algılanan örgütsel destek değişkeni ile ilişkinin (açıklayıcı gücünün) zayıf olduğu görülmektedir $\left(R^{2}=0,242\right)$. Çalışanların algıladıkları örgütsel desteğin samimi davranışı pozitif ve anlamlı olarak etkilediği tespit edilmiştir $(\beta \mathrm{j}=0,616)$. Bu doğrultuda, " $\mathrm{H}_{2}$ : Otel işletmeleri çalışanlarının örgütsel destek algılarının samimi davranış üzerinde pozitif yönlü ve anlamlı bir etkisi vardır" hipotezinin desteklendiği görülmüştür.

Lee ve diğerleri (2012) ve Oktuğ (2013) tarafından yapılan çalışmalarda da benzer bulgulara rastlanmış çalışanların algıladıkları örgütsel desteğin sergiledikleri samimi (doğal) davranışları üzerinde pozitif yönlü ve anlamlı bir etkisinin olduğu belirlenmiştir. Bulgular değerlendirildiğinde, otel işletmelerinin sahip olduğu örgütsel yapının destekleyici bir yapıda olması ve çalışanlara bir aidiyetlik duygusu hissettirmesi çalışanların hizmet sunumu sırasında misafirlere karşı daha fazla doğal duygular sergileme eğilimlerini arttıracağı şeklinde yorumlanabilir. Çalışanların müşterilere karşı doğal ve samimi duygular sergilemesi otel işletmeleri için müşteri memnuniyetinin artması ve müşteri sadakatinin sağlanması açısından katkı sağlayabileceği ve örgütsel başarıyı da arttırabileceği söylenebilir.

Tablo 6. Algılanan Örgütsel Desteğin Derin Davranış Üzerindeki Etkisine Yönelik Basit Doğrusal Regresyon Analizi

\begin{tabular}{lccccl}
\hline Bağımsız Değişken & $\boldsymbol{\beta j}$ & $\mathbf{S}(\mathbf{b j})$ & $\mathbf{t}$ & $\mathbf{p}$ & Anlamlılık \\
\cline { 1 - 5 } Sabit & 2,278 & 0,134 & 16,946 & 0,000 & \multirow{2}{F}{$=142,298$} \\
\cline { 1 - 4 } Algılanan Örgütsel Destek & 0,462 & 0,039 & 11,929 & 0,000 & $\mathrm{p}=0,000^{* *}$
\end{tabular}

Derin Davranış $=2,278+0,462 *$ Algılanan Örgütsel Destek

**: $p<0,001 ; R^{2}=0,208 ;$ Bağımlı Değişken: Derin Davranış

Algılanan örgütsel destek ile derin davranış arasındaki ilişkiyi belirlenmesi amacıyla yapılan regresyon analizi istatistiksel olarak anlamlı olduğu tespit edilmiştir ( $\mathrm{F}=142,298 ; \mathrm{P}=0,000)$. Derin davranışın belirleyicisi olarak algılanan örgütsel destek değişkeni ile ilişkinin (açıklayıcı gücünün) zayıf olduğu görülmektedir $\left(R^{2}=0,208\right)$. Çalışanların algıladıkları örgütsel desteğin derin davranışı pozitif ve anlamlı olarak etkilediği tespit edilmiştir $(\beta \mathrm{j}=0,462)$. Bu doğrultuda, " $\mathrm{H}_{3}$ : Otel işletmeleri çalışanlarının örgütsel destek algılarının derin davranış üzerinde pozitif yönlü ve anlamlı bir etkisi vardır" hipotezi desteklenmiştir.

Lee ve diğerleri (2012) ve Mishra (2013) konuyla ilgili yapmış oldukları çalışmalarda benzer sonuçları elde etmişler çalışanların örgütsel destek algılarının derin davranış sergileme eğilimlerini pozitif yönlü ve anlamlı bir etkisinin olduğunu tespit etmişlerdir. Bu durum, otel işletmelerindeki örgütsel yapının destekleyici olmasının çalışanların örgütlerine karşı aidiyet duygusunun artmasına katkı sağlayacağı ve desteklendiğini hisseden çalışanların örgüt tarafından istenen ve beklenen duyguları hissetmek ve sergilemek için elinden gelini yapmaya çalışacağı şeklinde açılanabilir. Oktuğ (2013) tarafından yapılan çalışma sonucunda diğer çalışmalara göre farklı bir sonuç elde edilmiş algılanan örgütsel desteğin derin davranış üzerinde negatif yönlü ve anlamlı bir etkisinin olduğu görülmüştür. 


\section{SONUÇ VE ÖNERILER}

Beş yıldızlı otel işletmeleri çalışanlarının algıladıkları örgütsel destek düzeyleri ve sergiledikleri duygusal emek davranışları belirlenerek, çalışanların örgütsel destek algılarının duygusal emek davranışları üzerindeki etkisinin belirlenmesini amaçlayan bu araştırmanın örneklem grubu farklı bireysel özelliklere sahip 544 çalışan oluşturmaktadır.

Araştırmada, algılanan örgütsel destek ile duygusal emek davranışları olan yüzeysel davranış, samimi davranış ve derin davranış arasında 0,001 anlamlılık düzeyinde ilişkinin olduğu belirlenmiştir. Algılanan örgütsel destek ile samimi davranış $(\mathrm{r}=0,491)$ ve derin davranış $(\mathrm{r}=0,456)$ arasında orta düzeyde anlamlı bir ilişki olduğu tespit edilmiştir. İlgili literatür incelendiğinde Lee ve diğerleri (2012) çalışanların örgütsel destek algıları ile samimi davranış ve derin davranış sergileme eğilimleri arasında pozitif yönlü bir ilişkinin olduğunu tespit etmişlerdir. Benzer şekilde Oktuğ (2013) yapmış olduğu çalışmada algılanan örgütsel destek ile samimi davranış ve derin davranış arasında olumlu yönde bir ilişkinin olduğunu belirtmiştir. Örgüt tarafından sağlanan desteğin çalışanların algıladığı ve örgüt tarafından istenen ve beklenen duyguları hissederek sergilemek için derin davranış gösterme eğilimi içerisinde oldukları ve bir süre sonra bir davranışlarını samimi davranışa dönüştürdükleri belirlenmiştir. Bununla birlikte, algılanan örgütsel destek ile yüzeysel davranış arasında $(\mathrm{r}=-0,246)$ düşük düzeyde anlamlı bir ilişki olduğu saptanmıştır. Mishra (2013) ve Kim ve diğerleri (2016) tarafından yapılan çalışmalarda çalışanların örgütsel destek alg1 düzeylerinin yüksek olmasının sergileme eğilimi içerisinde oldukları yüzeysel davranışı düşürdüğü görülmüştür. Otel işletmelerindeki örgütsel yapıların destekleyici olmasının çalışanların yüzeysel davranış sergileme eğilimlerini düşüreceği tespit edilmiştir.

Çalışanların algıladıkları örgütsel desteğin duygusal emek davranışları olan yüzeysel davranış, samimi davranış ve derin davranış üzerinde 0,001 anlamlılık düzeyinde ilişkinin olduğu görülmüştür. Çalışanların algıladıkları örgütsel desteğin yüzeysel davranışı negatif yönlü ve anlamlı olarak etkilediği tespit edilmiştir $(\beta \mathbf{j}=-0,275)$. Lee ve diğerleri (2012) tarafından yapılan çalışmada çalışanların örgütsel destek algılarının yüzeysel davranış sergileme eğilimlerinin düşürdüğü tespit edilmiştir. Mishra (2013) tarafından yapılan çalışmada da benzer şekilde çalışanların algılanan örgütsel destek düzeylerinin yüzeysel davranış sergileme eğilimlerini negatif yönlü etkilediği görülmüştür. Diğer bir duygusal emek davranış boyutları olan samimi davranış $(\beta \mathrm{j}=0,616)$ ve derin davranışı $(\beta \mathrm{j}=0,462)$ ise pozitif yönlü ve anlamlı olarak etkilediği görülmüştür. Lee ve diğerleri (2012) ve Mishra (2013) tarafından yapılan çalışmalarda da benzer şekilde algılanan örgütsel desteğin samimi davranış ve derin davranışı pozitif yönlü etkilediği belirlenmiştir. Bu sonuçlar doğrultusunda, çalışanların örgütsel destek algısının duygusal emek davranışlarından olan yüzeysel davranışı sergileme eğilimlerini düşürdüğü ve samimi davranış ile derin davranışs sergileme eğilimlerini ise arttırdığı şeklinde yorumlamak mümkündür. Bu doğrultuda algılanan örgütsel desteğin duygusal emek davranışları üzerindeki etkisini belirlemeye yönelik kurulan $\mathbf{H}_{1}, \mathbf{H}_{2}$ ve $\mathbf{H}_{3}$ hipotezleri desteklenmiştir.

$\mathrm{Bu}$ araştırmanın bulguları doğrultusunda elde edilen ve belirtilen sonuçlar çerçevesinde turizm sektörü ile ilgili çeşitli kurum, kuruluş, işletme ve turizm işletmelerinde çalışan üst kademe ve orta kademe yöneticilere ve özellikle insan kaynakları departmanı müdürlerine yönelik olarak sunulabilecek çeşitli öneriler şu şekilde özetlenebilir. Çalışanların örgütsel destek algılarına ve duygusal emek davranışlarına ilişkin sunulan öneriler şunlardır;

- Çalışanlarda destekleyici bir örgüt algısının oluşturulabilmesi için, çalışanların fikir, öneri ve eleştirileri dikkate alınmalı ve işleri ile ilgili alınacak kararlarda katkılarına başvurulmalı, ödül ve ceza sistemi oluşturulmalı ve çalışanlara karşı adil ve eşit davranış anlayışı benimsenmesi örgütsel destek algısı ve örgütsel bağlılı̆̆ı yüksek çalışanlara sahip olunması için işletmelere katkı sağlayabilir.

- Çalışanlara örgüt tarafından rahat ve huzurlu bir çalışma ortamı sunulması ve desteklenmesi, çalışanların işten ayrılma niyetine ilişkin düzeylerinin düşmesine katkı sağlayacaktır. Bu durum ise otel işletmeleri için çalışan devir hızının düşmesine ve devamlılığın sağlanmasına katkı sağlayarak personel bulma, seçme ve oryantasyon eğitimi gibi giderlerin düşmesine fayda sağlayabilir.

- Örgüt tarafından çalışanların işleri ile ilgili şikayetlerinin dikkate alınması, gösterdikleri ekstra çabanın takdir edilmesi ve örgüt yöneticileri tarafından çalışanlarla yakın ilişki kurulması çalışanların örgütsel destek algısının artmasına katkı sağlayabilir. 
- Çalışanların örgütsel destek algılarının arttırılması için çalışanlar ile örgüt arasında duygusal anlamda bir bağ kurulması ve çalışanın kendisini işletmenin sadece bir çalışanı olarak değil o ailenin bir parçası olduğunu hissetmesi sağlanarak, hizmet kalitesinin arttırılmasına, müşteri memnuniyeti ve sadakatinin sağlanmasına ve bununla birlikte, örgütsel başarının yükseltilmesine katkı sağlayabilir.

- İşletmelerde adil ücret sistemi, etkili performans değerlendirme sistemi ve objektif bir yönetim anlayışı benimsenerek çalışanların iş tatmini düzeylerinin arttırılması sağlanarak işletme tarafından istenen ve beklenen olumlu duygusal emek davranışlarının çalışanlar tarafından sergilenmesi sağlanabilir.

- İşletme tarafından çalışanlara eğitim desteği sağlanarak duygu yönetimi ile ilgili eğitimler verilmesi çalışanların sergileyeceği duyguları kontrol ve işletme tarafından istenen ve beklenen duyguları sergilemesi için işletmeler katkı sağlayabilir.

- Çalışanların örgüt tarafından desteklediğini hissetmesi çalışanların sergileyeceği yüzeysel davranışın azalmasına ve çalışanlarda yükümlülük duygusunun oluşması sonucunda işletme tarafından istenen duyguları sergilemek için çaba göstermesi derin davranış sergilemesine katkı sağlayacaktır. Çalışanların derin davranış sergileme eğilimi içerisine girmesi ve hizmet sunumu esnasında işletme tarafından istenen duyguları hissetmeye çalışması bir süre sonra samimi davranışa dönüşerek hizmet kalitesinin artmasına, müşteri memnuniyetinin sağlanmasına ve sadık müşterilerin oluşmasına bu durum sonucunda ise işletmenin rakiplerine karşı rekabet üstünlüğü sağlamasına katkı sağlayabilir.

- Turizm işletmelerinin emek-yoğun yapısı ve hizmetin üretildiği yerde tüketilmesi ve hizmet sunumu sırasında örgütün çalışanların sergilediği tutum ve davranışlar üzerindeki kontrolün minimum düzeyde olması ve çalışanların sergilediği davranışların müşterilerin hizmet kalitesi algılarına doğrudan etki etmesi örgütsel desteği işletmeler açısından önemli kılmaktadır. Örgütlerin destekleyici olması çalışanların sergileyeceği duygusal emek davranışlarını olumlu yönde etkileyerek hizmet kalitesinin artmasına ve müşteri memnuniyeti ve sadakati sağlanmasına katkı sağlayabilir.

Emek-yoğun yapısı ve hizmetin üretildiği yerde tüketilmesi özelliklerine sahip turizm sektöründe müşteri memnuniyeti ve sadakati sağlama zorunluluğu olan otel işletmelerinin çalışanlarını destekleyici davranması, çalışanların hizmet sunumu sırasında sergileyeceği davranışların ve sunulan hizmetin kalitesini doğrudan etki etmektedir. Bu araştırmada da ortaya konulduğu gibi, otel işletmelerinin çalışanlarını desteklemesi ve çalışanlarının örgütsel destek algılarının yükseltilmesi, çalışanların sergileyeceği duygusal emek davranışlarını olumlu yönde etkileyecek ve çalışanların hizmet sunumu esnasında doğal (samimi) davranışlar sergilemesine neden olabilecektir. Bu durumda müşterilerinin hizmet kalitesi algısını olumlu yönde etkileyerek müşteri memnuniyetinin artmasına ve sadık müşteriler oluşmasına katkı sağlayacaktır. Bununla birlikte örgütsel destek algısına sahip çalışanlar işletmelerine sıkı sıkıya bağlanarak işletmenin amaç ve hedeflerine ulaşması için elinden geleni yapacaklardır. Örgütsel destek algısı ve bağlılığı yüksek çalışanlara sahip işletmeler ise rakiplerine karşı rekabet üstünlügünü bir kat daha yükseltebileceklerdir.

Algılanan örgütsel desteğin duygusal emek davranışları üzerindeki etkisini belirlemeye yönelik farklı destinasyonlarda, beş yıldızlı otel işletmeleri dışında turizm sektöründe faaliyet gösteren diğer işletmelerde uygulama yapılarak karşılaştırma imkânı sağlanabilir. Bununla birlikte, farklı sektörlerde faaliyet gösteren işletmelerde de uygulanması ve konuyla ilgili farklılıkların ortaya konması, ilgili alan yazınına önemli ölçüde katkısının olacağı düşünülmektedir. 


\section{KAYNAKÇA}

Akbaba, A. (2011). Eğitim Müfettişleri için Örgüt ve Yönetim Algısı Ölçeği'nin Geliştirilmiş ve Mesleki Bazı Değişkenler Açısından Karşılaştırılması. Pegem Ĕ̆itim ve Öğretim Dergisi, 1(3), 67-79.

Anomneze, E. A., Ugwu, D. I., Enwereuzor, I. K. ve Ugwu, L. I. (2016). Teachers' Emotional Labour and Burnout: Does Perceived Organizational Support Matter?. Asian Social Science, 12(2), 9-22.

Armeli, S., Eisenberger, R., Fasolo, P. ve Lynch, P. (1998). Perceived organizational support of police performance: The moderating influence of sociemotional needs. Journal of Applied Psychology, (83), 288297.

Ashforth, B. E. ve Humphrey, R.H. (1993). Emotional Labor in Service Roles: The Influence of Identity, Academy of Management Review, 18(1), 88-115.

Ayana, Ç. (2016). Duygusal Zekâ ve Duygusal Emeğin Örgütsel Sinizm Algısına Etkisi: Beş Yıldızlı Otel İ̧̧letmelerinde Bir Uygulama, (Yayınlanmamış YL Tezi), Afyon Kocatepe Üniversitesi, Afyonkarahisar.

Basım, H. N. ve Beğenirbaş, M. (2012). Çalışma Yaşamında Duygusal Emek: Bir Ölçek Uyarlama Çalışması. Celal Bayar Üniversitesi İktisadi ve İdari Bilimler Fakültesi Yönetim ve Ekonomi Dergisi, 19(1), 77-90.

Başbuğ, G., Ballı, E. ve Oktuğ, Z. (2010). Duygusal Emeğin İş Memnuniyetine Etkisi: Çağrı Merkezi Çalışanlarına Yönelik Bir Çalışma, Sosyal Siyaset Konferansları Dergisi, (58), 253-274.

Beğenirbaş, M. ve Meydan, C. H. (2012). Duygusal Emeğin Örgütsel Vatandaşlık Davranışıyla İlişkisi: Öğretmenler Üzerinde Bir Araştırma, Gazi Üniversitesi İktisadi ve İdari Bilimler Fakültesi Dergisi 14(3), 159-181.

Biçkes, D. M., Yılmaz, C., Demirtaş, Ö. ve Uğur, A. (2014). Duygusal Emek ile İş Tatmini Arasındaki İlişkide Psikolojik Sermayenin Aracılık Rolü: Bir Alan Çalışması, Eskişehir Osmangazi Üniversitesi İktisadi ve İdari Bilimler Fakültesi Dergisi, 9(2), 97-121.

Brotheridge, C. M. ve Lee, R. T. (2003). Development and validation of the Emotional Labour Scale. Journal of Occupational and Organizational Psychology, 76(3), 365-379.

Büyüköztürk, Ş. (2003). Sosyal Bilimler İçin Veri Analizi El Kitabı, Ankara: Pegem Akademi Yayıncllık.

Chu, K. H. L. ve Murrmann, S. K. (2006). Development and Validation of The Hospitality Emotional Labor Scale, Tourism Management, 27(6), 1181-1191.

Çoruk, A. (2014). Yükseköğretim Kurumlarında Görev Yapan İdari Personelin Duygusal Emek Davranışları, Ondokuz Mayıs Üniversitesi Ĕ̆itim Fakültesi Dergisi, 33(1), 79-93.

Çoşkun, R., Altunışık, R. ve Yıldırım, E. (2017). Sosyal Bilimlerde Araştırma Yöntemleri SPSS Uygulamalı, (5.Baskı). Sakarya: Sakarya Yayıncllık.

Delay, M. T. (1999). Emotional Labour in the Workplace, (Unpublished Master Thesis), University of Arkansas, Little Rock.

Diefendorff, J. M. ve Gosserand, R. H. (2003). Understanding the emotional labor process: A control theory perspective. Journal of Organizational Behavior, 24(8), 945-959.

Diefendorff, J. M., Croyle, M. H. ve Gosserand, R. H. (2005). The dimensionality and antecedents of emotional labor strategies. Journal of Vocational Behavior, 66(2), 339-357.

Diefendorff, J.M. ve E.M. Richard, E. M. (2008). Not All Emotional Display Rules are Created Equal Distinguihing Between Prescriptive and Contextual Display Rules. N. M. Ashkanasy \& L. C. Cooper (Ed.) Research Companion To Emotion in Organizations, United Kingdom: Edward Elgar Publishings. 
M. Gülaydın - G. Aytaş 12/4 (2020) 3433-3450

Durmuş, V. ve Şahin, B. (2015). Hastanelerde Algılanan Örgütsel Destek ile Örgütsel Öğrenme Arasındaki İlişkinin Belirlenmesine Yönelik bir Araştırma. TAF Preventive Medicine Bulletin, 14(6), 438-447.

Eisenberger, R., Fasolo, P., ve Davis-LaMastro,V. (1990). Perceived organizational support and employee diligence, commitmentand innovation, Journal of Applied Psychology, (75), 51-59.

Eisenberger, R., Huntington, R., Hutchison, S. ve Sowa, D. (1986). Perceived Organizational Support. Journal of Applied Psycology, (7), 500-507.

Eroğlu, E. (2010). Örgütsel İletişimin İşgörenlerin Duygu Gösterimlerinin Yönetimine Olan Etkisi. Selçuk Üniversitesi İletişim Fakültesi Akademik Dergisi, 6(3), 18-33.

Eroğlu, Ş. G. (2014). Örgütlerde Duygusal Emek ve Tükenmişlik İlişkisi Üzerine Bir Araştırma, Pamukkale Üniversitesi Sosyal Bilimler Enstitüsü Dergisi, (19), 147-160.

Goffman, E. (1959). The Presentation of Self in Everyday Life, New York: Doubleday Anchor.

Gosserand, R. H. ve Dienfendorff, J. M. (2005). Display Rules and Emotional Labor: The Moderating Role of Commitment, Journal of Applied Psychology, 90(6), 1256-1264.

Grandey, A. A. (1999). The effects of emotional labor: Employee attitudes, stres and performance, (Unpublished Doctoral Dissertation), Colorado: Colorado State University.

Hochschild, A. R. (1983). The Managed Heart: The Commercialization of Human Feeling. Berkeley: University of California Press.

Hur, C. ve Kim, T. (2014). Effect of KORAIL Tour Conductors' Emotional Labor on Customer Orientation: Moderating Effect of Perceived Organizational Support, Journal Of The Korean Society For Railway, 17(4), 289-296.

Hur, W., Han, S., Yoo, J. ve Moon, T. (2014). The Moderating Role of Perceived Organizational Support on the Relationship Between Emotional Labor and Job-Related Outcomes, Management Decision, 53(3), 605624.

Hur, W., Moon, T. W. ve Jun, J. (2012). The Role of Perceived Organizational Support on Emotional Labor in the Airline Industry, International Journal of Contemporary Hospitality Management, 25(1), 105-123.

İplik, E., İplik, F. N., ve Efeoğlu, E. (2014). Çalışanların Örgütsel Destek Algılarının Örgütsel Vatandaşlık Davranışı Üzerindeki Etkisinde Örgütsel Özdeşleşmenin Rolü. International Journal of Economic and Administrative Studies, 6(12), 109-122.

Kaplan, M. (2010). Otel İşletmelerinde Etiksel İklim ve Örgütsel Destek Algılamalarının Örgütsel Bağhllık Üzerindeki Etkisi (Kapadokya Örneği), (Yayınlanmamış Doktora Tezi), Selçuk Üniversitesi, Konya.

Karaman, N. (2017). Çalışma Yaşamında Duygusal Emek, İş ve Hayat Dergisi, 30-57.

Karasar, N. (2008). Bilimsel Araştırma yöntemi. Ankara: Nobel Yayın Dağıtım.

Kart, E. (2011). Bir Duygu Yönetimi Süreci Olarak Duygusal Emeğin Çalışanlar Üzerindeki Etkisi. Çalışma ve Toplum, (3), 215-230.

Kaya, B. (2012). Algılanan Örgütsel Destek Düzeyinin ve Çalışanların Kariyer Tatmininin İşten Ayrılma Niyeti Üzerindeki Etkileri: Konaklama İşletmelerinde Bir Uygulama, (Yayınlanmamış YL Tezi), Akdeniz Üniversitesi, Antalya.

Keleş, Y. (2014). Örgütsel Adaletin Duygusal Emek Üzerindeki Etkisi: Antalya'daki Beş Yıldızlı Otel İşletmelerinde Bir Araştırma, (Yayınlanmamış Doktora Tezi), Gazi Üniversitesi, Ankara. 
M. Gülaydın - G. Aytaş 12/4 (2020) 3433-3450

K1lıç. G. (2008). Kariyer Yönetimi ve Örgütsel Bağhllık Arasındaki İlişki: Beş Yıldızlı Otel İşletmelerinde Bir Araştırma, (Yayınlanmamış Doktora Tezi), Gazi Üniversitesi, Ankara.

Kızanlıklı, M. (2014). Otel İşletmelerinde Duygusal Emek Öncüllerini Belirlenmesine Yönelik Bir Araştırma, (Yayınlanmamış Doktora Tezi), Gazi Üniversitesi, Ankara.

Kim, H. J., Hur, W. M., Moon, T. W. ve Jun, J. K. (2016). Is All Support Equal? The Moderating Effects of Supervisor, Coworker, and Organizational Support on the Link Between Emotional Labor and Job Performance, Business Research Quarterly, (20), 124-136.

Köse, S., Oral, L. ve Türesin, H. (2011). Duygusal Emek Davranışlarının İşgörenlerin Tükenmişlik Düzeyleri ile İlişkisi Üzerine Sağlık Sektöründe Bir Araştırma. Işletme Fakültesi Dergisi, 12(2), 165-185.

Kruml, S. M. ve Geddes, D. (2000). Exploring the dimensions of emotional labor. Management Communication Quarterly, 14(1), 8-49.

Lee, D. C., Hung, L. M. ve Huang, S. C. (2012). Does Job Enjoyment and Organizational Support Affect Emotional Labor?. Journal of Business Research-Turk, 4(2), 5-29.

Mishra, K. S. (2013). Linking Perceived Organizational Support to Emotional Labor, Personnel Review, 43(6), 845-860.

Oğuz, H. ve Özkul, M. (2016). Duygusal Emek Sürecine Yön Veren Sosyolojik Faktörler Üzerine Bir Araştırma: Batı Akdeniz Uygulaması. Süleyman Demirel Üniversitesi Vizyoner Dergisi, 7(16), 130-154.

Oktuğ, Z. (2013). Algılanan Örgütsel Destek ile Duygusal Emek Davranışları Arasındaki İlişkide Algılanan Örgütsel Prestijin Biçimlendirici Etkisi, Elektronik Sosyal Bilimler Dergisi, 12(46), 370-381.

Onay, M. (2011), Çalışanın Sahip Olduğu Duygusal Zekasının ve Duygusal Emeğinin, Görev Performansı ve Bağlamsal Performans Üzerindeki Etkisi, Ege Akademik Bakış Dergisi, 11(4), 587-600.

Özdamar, K. (2001). SPSS ile Biyoistatistik, 4. Baskı, Kaan Yayınları, Eskişehir

Özdemir, A. (2010). Örgütsel Özdeşleşmenin Algılanan Örgütsel Destek, Cinsiyet ve Kıdem Değişkenlerine Göre İncelenmesi. Türkiye Sosyal Araştırmalar Dergisi, 14(1), 238-250.

Özdevecioğlu, M. (2003). Algılanan Örgütsel Destek ile Örgütsel Bağl1lık Arasındaki İlişkilerin Belirlenmesine Yönelik Bir Araştırma. Dokuz Eylül Üniversitesi İktisadi İdari Bilimler Fakültesi Dergisi, 2(18), 113-130.

Özkan, G. (2013). Çağrı Merkezlerinde Duygusal Emek ve Örgütsel İletişim. Selçuk Üniversitesi İletişim Fakültesi Akademik Dergisi, 7(4), 64-80.

Pelit, E. (2011). Otel İşletmelerinde Operasyonel Risk Yönetimi: Ankara'daki Dört ve Beş Yıldızlı Otel İşletmelerinde Bir Araştırma, Business and Economics Research Journals, 2(2), 117-137.

Rhoades, L. ve Eisenberger, R. (2002). Perceived Organizational Support: A Review of the Literature. Journal of Applied Psychology, 87(4), 698-714.

Robbins, S. P. ve Judge, T. (2013). Organizational behavior, (15th edition), Boston: Pearson.

Rousseau, D. M. (1995). Psychological Contracts in Organizations: Understanding Written and Unwritten Agreements, Newbury Park, CA: Sage.

Steinberg, R. J. ve Figart, D. M. (1999). Emotional Demands at Work: A Job Content Analysis. The Annals of the American Academy of Political and Social Science, (561), 177-191.

Topateş, H. ve Kalfa, A. (2009). Yeni Çalışma İlişkileri Bağlamında Örgütsel Yurttaşlık ve Duygusal Emek. Uluslararası Sosyal Haklar Sempozyumu. Akdeniz Üniversitesi, Antalya, 423-431. 
M. Gülaydın - G. Aytaş 12/4 (2020) 3433-3450

Turunç, Ö. ve Çelik, M. (2010b). Algılanan Örgütsel Desteğin Çalışanların İş-Aile, Aile-İş̧ Çatışması, Örgütsel Özdeşleşme ve İşten Ayrılma Niyetine Etkisi: Savunma Sektöründe Bir Araştırma. Atatürk Üniversitesi Sosyal Bilimler Enstitüsü Dergisi, 14(1): 209-232.

Ural, A. ve Kılıç, İ. (2018) Bilimsel Araştırma Süreci ve Spss ile Veri Analizi, (5.Baskl). Ankara: Detay Yayıncılık.

Yılmaz, A. (2016). Algılanan Örgütsel Destek Ortamında İş Stresi ve İş Yaşam Kalitesinin İş Performansı Üzerine Etkisinin Araştırılması: İstanbul'da Bulunan Beş Yıldızlı Otellerde Çalışan Aş̧̧lar Üzerine Bir Araştırma, (Yayınlanmamış Doktora Tezi), İstanbul Üniversitesi, İstanbul.

Yılmaz, E. (2014). Duygusal Emeğin Tükenmişlik ve İşten Ayrılma Niyeti Üzerine Etkisi: Algılanan Örgütsel Desteğin Biçimlendirici Rolü, (Yayınlanmamış YL Tezi), Çanakkale Onsekiz Mart Üniversitesi, Çanakkale.

Yim, Y. C. F. (2014). An Empirical Study on the Effects of Emotional Labour, Perceived Organisational Support and Perceived Supervisor Support on Tour Guides' Role Performance in Hong Kong, (Unpublished Doctoral Dissertation), Southern Cross University, Australia.

Zagenczyk, T. J. (2006). A Social Influence Analysis of Perceived Organizational Support, (Unpublished Doctoral Dissertation), University of Pittsburgh, Pennsylvania.

http://www.afyonkulturturizm.gov.tr/TR,158749/kultur-turizm-istatistikleri.html (Erişim: 01.06.2018) 